\title{
Relationship of Nutritional Status to Incidency Symptom Respiratory on Online Ojek Drivers in Malang City, East Java, Indonesia
}

\author{
Salwa Rizqi Salsabila ${ }^{1}$, Hanna Cakrawati ${ }^{2}$, Thahri Iskandar ${ }^{3}$ \\ ${ }^{1}$ Medical Faculty of Muhammadiyah Malang University, Malang, East Java, Indonesia, 65144 \\ ${ }^{2}$ Neurologist at Medical Faculty of Muhammadiyah Malang University, Malang, East Java, Indonesia, 65144 \\ ${ }^{3}$ Radiologist at Medical Faculty of Muhammadiyah Malang University, Malang, East Java, Indonesia, 65144
}

Corresponding Author: Salwa Rizqi Salsabila

\begin{abstract}
Backgrounds/Aims: Respiratory disease is one of occupational disease that increasing and becoming the biggest three diseases that contribute more than three-quarters of total work-related deaths with circulations disease and neoplasm. Exposure to dust, allergens and toxins are some of the risk factors for respiratory diseases. One of the jobs with a high risk of exposure to air pollution is online motorcycle taxi drivers, they inhale pollution from the transportation sector and pollutant gases in the air which can cause respiratory problems. In addition, nutrition and respiratory disorders have an important relationship. In the recovery process, nutritional status has an important impact in the process of breaking down proteins contained in muscles including respiratory muscles in the catabolism process.
\end{abstract}

Methods: This study was an analytic observation and the data was collected retrospectively in online motorcycle taxi drivers in Malang City with inclusion criteria on April 2021.

Results: 108 online motorcycle taxi drivers in Malang, aged 15-55 years, 96.3\% men, respiratory disorders $76.9 \%$ respondents with 93.6\% underweight. Respiratory symptom more having common cold $66,7 \%$, cough $42,6 \%$ and phlegm 38,9\%. The relationship between nutritional status and the incidence of respiratory symptoms was 8.1 times (95\% CI $(1.9-16.4) \mathrm{p}=0.017)$

Conclusions: There is a significant relationship between nutritional status and symptoms of respiratory disorders in online motorcycle taxi drivers in Malang City with 8 times.

Keywords: acute ischemic, stroke, platelet lymphocyte ratio, poor outcome

\section{INTRODUCTION}

Occupational diseases account for $5 \%$ of deaths globally. One of the occupational diseases is respiratory disorders, these diseases have increased and become the three biggest diseases after circulation diseases and neoplasms. These three diseases account for more than threequarters of total work-related deaths. [1]

Some of the risk factors for occupational respiratory diseases include exposure to dust, allergens and toxins that can cause oxidative damage. [2] One of the jobs with a high risk of exposure to air pollution is an online motorcycle taxi driver. Irregular working hours can cause online motorcycle taxi drivers to breathe old air pollution due to working all day on the highway, resulting in respiratory health complaints. The source of the entry of air pollution into the breathing of online motorcycle taxi drivers is the transportation sector and pollutant gases in the air which can cause respiratory tract disorders. [3]

According to WHO, the health effects of exposure to air pollution in a short time can affect the reaction of pneumonia, ARI (acute respiratory infection to death. 
While the long-term effects are symptoms of lower respiratory tract disorders, asthma exacerbations, decreased lung function, increased obstructive pulmonary disease). chronic, decreased average life expectancy, especially death caused by cardiopulmonary disease and the probability of lung cancer incidence. [4] COPD is one of the highest diseases of the respiratory system caused by work. Work with a high risk of exposure to air causes a chronic inflammatory process caused by air polluting substances. $[5,6]$

Nutrition and disorders of the respiratory system have an important relationship. In the recovery process, nutritional status has an important impact on the process of breaking down proteins contained in the muscles, including the respiratory muscles in the catabolism process. If the calorie intake is reduced, muscle mass also disappears and will have an impact on muscle function. [7]

In Indonesian society, there are still many sufferers of diseases related to malnutrition. One of the factors that affect a person's level of health is good nutritional status. People with good nutritional status are not susceptible to disease, both infectious and degenerative diseases. One of the important factors in achieving optimal health is having a good nutritional status [8]. However, in Indonesia the problem of malnutrition is still high, on the other hand the problem of excess nutrition is increasing, especially in big cities. Overweight and obesity are seen in all age groups and socioeconomic strata. [3]

\section{METHOD}

This study is an analytic observational study with a cross sectional design to determine the relationship between nutritional status and the incidence of respiratory symptoms among online motorcycle taxi drivers in Malang City. The study was conducted in Malang City in April 2021. The data obtained were based on the questionnaire results from online motorcycle taxi drivers in Malang City who met the inclusion criteria. Inclusion data includes online motorcycle taxi drivers who are willing to be research respondents, work at least one year and work at least five days a week.

\section{RESULT}

Table 1 Demographic Characteristics of Respondents

\begin{tabular}{|c|c|c|c|}
\hline \multicolumn{2}{|l|}{ Variable } & \multirow{2}{*}{$\begin{array}{l}\text { Frequency } \\
101 \\
\end{array}$} & \multirow{2}{*}{$\begin{array}{l}\begin{array}{l}\text { Percentage } \\
\text { (\%) }\end{array} \\
93.5 \%\end{array}$} \\
\hline Age & $15-55$ years old & & \\
\hline & $>55$ years old & 7 & $6.5 \%$ \\
\hline & mean \pm SD & $32.4 \pm 8.1$ & \\
\hline \multirow[t]{5}{*}{ Height } & $<150 \mathrm{~cm}$ & 1 & $0.9 \%$ \\
\hline & $150-159 \mathrm{~cm}$ & 11 & $10.2 \%$ \\
\hline & $160-169 \mathrm{~cm}$ & 52 & $48.1 \%$ \\
\hline & $>=170 \mathrm{~cm}$ & 44 & $40.7 \%$ \\
\hline & $\begin{array}{l}\text { mean } \pm \text { SD } \\
162.4 \pm 8.9\end{array}$ & & \\
\hline \multirow[t]{5}{*}{ Weight } & $<50 \mathrm{~kg}$ & 4 & $3.7 \%$ \\
\hline & $50-69 \mathrm{~kg}$ & 67 & $62.0 \%$ \\
\hline & $70-89 \mathrm{~kg}$ & 34 & $31.5 \%$ \\
\hline & $>=90 \mathrm{~kg}$ & 3 & $2.8 \%$ \\
\hline & $\begin{array}{l}\text { mean } \pm \text { SD } \\
59.4 \pm 11.4\end{array}$ & & \\
\hline \multirow{7}{*}{$\begin{array}{l}\text { Symptoms of } \\
\text { Respiratory } \\
\text { Disorders }\end{array}$} & Cough & 46 & 42.6 \\
\hline & phlegm & 42 & 38.9 \\
\hline & Hard to breathe & 3 & 3.8 \\
\hline & Wheeze/wheezing & 7 & 6.5 \\
\hline & Chest feels heavy & 16 & 14.8 \\
\hline & $\begin{array}{l}\text { Having common } \\
\text { cold }\end{array}$ & 72 & 66.7 \\
\hline & Sore throat & 24 & 22.2 \\
\hline \multirow{4}{*}{$\begin{array}{l}\text { Nutritional } \\
\text { status }\end{array}$} & Underweight & 16 & $14.8 \%$ \\
\hline & Overweight & 32 & $29.6 \%$ \\
\hline & Normal & 60 & $55.6 \%$ \\
\hline & Average BMI & & \\
\hline \multirow{2}{*}{$\begin{array}{l}\text { Symptoms of } \\
\text { respiratory } \\
\text { disorders }\end{array}$} & Not & 25 & $23.1 \%$ \\
\hline & Yes & 83 & $76.9 \%$ \\
\hline
\end{tabular}

Table 2 Bivariate Analysis of nutritional status on symptoms of respiratory disorders in online motorcycle taxi drivers in the city of Malang

\begin{tabular}{|l|l|l|l|l|l|l|}
\hline Variable & \multicolumn{2}{|l|}{ respiratory symptoms } & OR & $95 \%$ CI & P value) \\
\cline { 3 - 4 } & Yes & Not & & & \\
\hline \multirow{2}{*}{ Nutritional status } & Overweight to obesity & $28(87.5 \%)$ & $4(12.5 \%)$ & 8.107 & $1.9-16.4$ & $0.017 *$ \\
\cline { 2 - 3 } & Normal & $40(66.7 \%)$ & $20(33.3 \%)$ & & & \\
\hline \multicolumn{7}{|l|}{ *Significant } \\
\hline
\end{tabular}

The study was conducted on 108 online motorcycle taxi drivers in Malang City. The data was obtained based on the results of questionnaire answers and BMI calculations based on measurements of TB (Height) and BB (Weight) to determine the 
relationship between nutritional status and the incidence of respiratory symptoms among online motorcycle taxi drivers in Malang City. The characteristics of this research are obtained in table $\mathbf{1 .}$

In this study, to examine the relationship between nutritional status and the incidence of respiratory symptoms in online motorcycle taxi drivers in Malang City, a bivariate analysis was carried out with the Chi-Square test obtained in table 2.

\section{DISCUSSION}

This research was conducted on 108 online motorcycle taxi drivers in Malang City according to the inclusion criteria. The data obtained were based on the results of questionnaire answers and BMI calculations based on measurements of height and weight (TB/BB) to determine the relationship between nutritional status and the incidence of respiratory symptoms among online motorcycle taxi drivers in Malang City. There were no respondents with drop out criteria during the research process. This study was conducted with the aim of knowing the relationship between nutritional status and symptoms of respiratory disorders in online motorcycle taxi drivers in Malang City.

Based on the questionnaire (Table 1) from 108 respondents, there were no respondents aged less than 15 years, 101 respondents aged $15-25$ years (93.5\%), and 7 respondents aged more than 55 years (6.5\%). Based on the data, it was found that the majority of online motorcycle taxi drivers in Malang City are 15-55 years old. This is in accordance with Ukkas (2017) that the age level of the productive workforce is in the age range of 15-55 years.[9]The gender of the 108 respondents of online motorcycle taxi drivers in Malang City found 4 (3.7\%) female respondents and 96.3\% male respondents. This shows that the majority of online motorcycle taxi workers in Malang City are male. According to Kurniawan 2020, online motorcycle taxi drivers are dominated by men, but female online motorcycle taxi drivers are also starting to develop.[10]

Based on the results of the BMI calculation by interpreting it into three categories, namely Underweight, Overweight and Normal, from 108 respondents, data obtained as much as $14.8 \%$ of respondents with Underweight conditions, $29.6 \%$ of respondents with Overweight conditions and $55.6 \%$ of respondents with normal bodies. This shows that from the number of online motorcycle taxi drivers in Malang, the majority of respondents are respondents with normal nutritional status. The results obtained are no symptoms of respiratory disorders were $23.1 \%$, while $76.9 \%$ of other respondents experienced symptoms of respiratory disorders. The most common respiratory symptoms experienced were runny nose with a percentage of $66.7 \%$, coughing by $42.6 \%$, phlegm by $38.9 \%$, sore throat by $22.2 \%$, chest tightness by $14.8 \%$, wheeze/wheezing. by $6.5 \%$ and shortness of breath by $3.8 \%$.

Respiratory disorders were more common in respondents with overweight and underweight BMI. On the other hand, respondents with a normal BMI tend to have no symptoms of respiratory disorders compared to the overweight and underweight groups. Based on the test results using the chi-square value to determine the relationship between nutritional status and symptoms of respiratory disorders, risk of symptom of respiratory is 8.107 times, with a significance value (p) of 0.017 which is smaller than alpha 0.05 and it can be concluded that there is a significant (meaningful) relationship between nutritional status and the incidence of respiratory symptoms among motorcycle taxi drivers in Malang City.Based on the Odd Ratio calculation, it can be concluded that online motorcycle taxi drivers with overweight BMI increase the risk of possible occurrence of respiratory symptoms by 8 times compared to normal. On research (Supriadi, 2017) with the 
method of comparing the condition of underweight and overweight patients in PID (Primary Immunodeficiency Disease) patients and a statement stating that nutritional status has a correlation with the immune system. [12] This is because the nutritional status of obesity is characterized by an increase in inflammation due to an increase in proinflammatory cytokines, including TNF- $\alpha$ (tumor necrosis factor- $\alpha$ ) which is produced in fat mass and TNF- $\alpha$ is not influenced by other factors so that it can be an independent indicator for obesity. mortality. An increase in inflammation will increase the production of free radicals, one of which is ROS (reactive oxygen species) which can damage cells.[11] Increased ROS that causes oxidative stress will result in activation of proinflammatory transcription nuclear factor-KB, p38 mitogen-activated protein kinase, generate autoantibodies to carbonylated protein, decrease sirtuin-1, DNA damage, decrease histone deacetylase (HDAC-2), decrease antiproteases and increase TGF- $\alpha$. Furthermore, oxidative stress that affects the balance between proteolytic and anti-proteolytic in the lung causes parenchymal damage so that if it continues, emphysema can occur.[13].

The nutritional status of obesity has a relationship with metabolic disorders that can cause stress and tissue dysfunction. In obese people the risk of chronic disease is greater, as indicated by the clinical parameters of the metabolic syndrome (MetS), insulin resistance and systemic markers of low-grade chronic inflammation. In inflammatory conditions, adipose hypertrophy will result in leukocyte dysfunction in adipose tissue, this is due to the production of resistant and IL-1b. Meanwhile, hypertrophy in adipose and macrophages can increase the secretion of TNF-, IL-6 and monocyte chemoattractant protein-1.[14] According to research conducted by Rugner (2018) obesity has a relationship with reduced number and function of NK-cells and lymphocyte proliferation in response to mitogens.[12]Increased adipose tissue has been associated with adipose dysfunction immune dysregulation, which results in high circulating levels of pro-inflammatory cytokines, such as TNF $\alpha$, IL-6 and IL-18. This process is quite complex and depends on lymphocytes and macrophages infiltrating the tissue[12].

Under conditions of underweight nutritional status, it causes several things such as a decrease in Th2 cytokines such as IL4 and IL10, Th1 cytokines such as IL2, IL12 and IFN $\beta$ decrease. Until the nutritional status of underweight that is too severe can result in decreased secretion of IgA, increased inflammatory cells in the intestine, microbicidal activity in granulocytes, decreased dendritic cells, decreased complement factors in the blood, decreased delayed-type hypersensitivity, decreased effector $\mathrm{T}$ cells, increased apoptosis in lymphocytes, B-cells in the blood decrease, IgA in the blood increases until the response to vaccination titers decreases[15].

In the condition of underweight nutritional status, there is a correlation with lung function parameters such as a decrease in FEV1, predicted FEV1 (\%), FVC, predicted FVC (\%) and PEF. Several reasons why underweight nutritional status is associated with decreased lung function. Low muscle mass in underweight is one of the causes. Several studies have reported that low lung function is associated with reduced skeletal muscle mass, especially diaphragmatic muscle mass, which has been reported to be reduced in lean populations. Theoretically, loss of intercostal and abdominal muscle mass can affect respiratory and muscle strength. In the adult population study conducted by Jeon (2015) low lung function, FVC, and FEV1 were associated with low muscle mass.[16] In the Do (2019) study, low muscle mass in underweight populations can result in low lung function. [17]

In addition to nutritional status, there are factors that support the occurrence of symptoms of respiratory disorders in online motorcycle taxi drivers because they have 
Salwa Rizqi Salsabila et.al. Relationship of nutritional status to incidency symptom respiratory on online ojek drivers in Malang City, East Java, Indonesia.

the risk of being exposed to air pollution which has an impact on the respiratory system. The exposure can be in the form of pollutants such as 1,3-butadiene, benzene, toluene, ethylbenzene, nitrogen oxides, carbon monoxide, carbon black and particles $<2.5 \mathrm{~m}$ and $<0.1 \mathrm{~m} 2$. Research shows that air pollution reduces mucociliary hygiene by $32 \%$, increases the body's inflammatory response and causes clinical symptoms in motorcyclists who work 8-12 hours per day and 5 days per week. Thus, it can lead to long-term effects on health in the form of chronic lung disease, an increase in the scale of exacerbations and hospital visits. [18] This can be exacerbated by overweight or underweight nutritional status which will affect the body both immunologically and physiologically. $[12,17]$

Good nutritional status (Normal) is expected to reduce the risk of symptoms of respiratory disorders. This is in accordance with Bhatti's research (2019) using spirometry in adults to assess the relationship between body mass index and body mass index, which found a significant relationship between body mass index and lung function parameters.[19] Overweight is also a detrimental influence on the respiratory physiology of a healthy person.

\section{CONCLUSION}

Nutritional status of online motorcycle taxi drivers in Malang City is normal and significant relationship between nutritional status and symptoms of respiratory disorders in online motorcycle taxi drivers in Malang City with 8 times.

\section{Funding}

This work did not receive any grant from funding agencies in the public, commercial, or not-for-profit sectors.

\section{Ethical Approval}

This study has obtained ethical clearance issued by the Research Ethic Commission of Faculty of Medicine,
Muhammadiyah Malang University, Malang, East Java, Indonesia

\section{Acknowledgement: None}

Conflict of Interest: There are no conflicts of interest to declare by any of the authors of this study.

\section{REFERENCES}

1. Wang H, Naghavi M, Allen C, Barber RM, Carter A, Casey DC, et al. Global, regional, and national life expectancy, all-cause mortality, and cause-specific mortality for 249 causes of death, 1980-2015: a systematic analysis for the Global Burden of Disease Study 2015. Lancet. 2016;388(10053):1459-544.

2. Päivi Hämäläinen JT\& TBK. Global Estimates of Occupational Accidents and Work-related Illnesses 2017. Work Saf Heal institute, Finl. 2017;1-21.

3. Kurdanti W, Suryani I, Syamsiatun NH, Siwi LP, Adityanti MM, Mustikaningsih D, et al. Faktor-faktor yang mempengaruhi kejadian obesitas pada remaja. J Gizi Klin Indones. 2015;11(4):179.

4. WHO. Evolution of WHO air quality guidelines. Copenhagen: WHO Regional Office for Europe. 2017.

5. Rycroft CE, Heyes A, Lanza L, Becker K. Epidemiology of chronic obstructive pulmonary disease: A literature review. Int $\mathrm{J}$ COPD. 2012;7:457-94.

6. Raherison C, Girodet PO. Epidemiology of COPD. Eur Respir Rev. 2009;18(114):21321.

7. Ariyani DR. Hubungan Antara Status Gizi Dan Pola Makan Dengan Fungsi Paru Pada Pasien Penyakit Paru Obstruktif Kronik (Ppok) Di Balai Besar Kesehatan Paru Masyarakat. Gambaran Perkemb Otak Pasca Stroke Setelah Dilakukan Akt Otak. 2013;

8. Harjatmo TP, Par'i HM, Wiyono S. Penilaian Status Gizi. Kementrian Kesehat Republik Indones. 2017;5(1):1-8.

9. Ukkas I. Faktor-Faktor Yang Mempengaruhi Produktivitas Tenaga Kerja Industri Kecil Kota Palopo. Kelola J Islam Educ Manag. 2017;2(2).

10. Kurniawan F, Soenaryo SF. Menaksir Kesetaraan Gender Dalam Profesi Ojek Online Wanita Di Kota Malang. J Sosiol Pendidik Humanis. 2020;4(2):115. 
Salwa Rizqi Salsabila et.al. Relationship of nutritional status to incidency symptom respiratory on online ojek drivers in Malang City, East Java, Indonesia.

11. Supriadi R, Christina, Soelaeman MR. Perbedaan Kadar Vitamin E dan Tumor Necrosis Factor Alpha (TNF- $\alpha$ ) berdasar atas Status Massa Lemak Pasien dalam Hemodialisis Kronik. Maj Kedokt Bandung. 2017;49(3):192-8.

12. Ruffner MA, Sullivan KE. Complications Associated with Underweight Primary Immunodeficiency Patients: Prevalence and Associations Within the USIDNET Registry. J Clin Immunol. 2018;38(3):28393.

13. Barnes PJ. Cellular and molecular mechanisms of asthma and COPD. Clinical Science. 2017.

14. Andersen CJ, Murphy KE, Fernandez ML. Impact of obesity and metabolic syndrome on immunity. Adv Nutr. 2016;7(1):66-75.

15. Rytter MJH, Kolte L, Briend A, Friis H, Christensen VB. The immune system in children with malnutrition - A systematic review. PLoS One. 2014;9(8).

16. Jeon YK, Shin MJ, Kim MH, Mok JH, Kim SS, Kim BH, et al. Low pulmonary function is related with a high risk of sarcopenia in community-dwelling older adults: the Korea
National Health and Nutrition Examination Survey (KNHANES) 2008-2011. Osteoporos Int. 2015;

17. Do JG, Park CH, Lee YT, Yoon KJ. Association between underweight and pulmonary function in 282,135 healthy adults: A cross-sectional study in Korean population. Sci Rep. 2019;9(1):14308.

18. Brant TCS, Brant TCS, Yoshida CT, Carvalho TS, Nicola ML, Martins JA, et al. Mucociliary clearance, Airway inflammation and nasal symptoms in urban motorcyclists. Clinics. 2014;69(12):867-70.

19. Bhatti U, Ali Laghari Z, Syed BM. Effect of body mass index on respiratory parameters: A cross-sectional analytical study. Pakistan J Med Sci. 2019;35(6):1724-9.

How to cite this article: Salwa Rizqi Salsabila, Hanna Cakrawati, Thahri Iskandar. Relationship of nutritional status to incidency symptom respiratory on online ojek drivers in Malang City, East Java, Indonesia. International Journal of Research and Review. 2021; 8(12): 644-649. DOI: https://doi.org/10.52403/ijrr.20211279 